\title{
Formation of the infrastructure of the waste processing cluster
}

\author{
Elena Serebryakova ${ }^{1,{ }^{*}}$, Elena Smorodina ${ }^{1}$, Oksana Belyantseva $^{1}$, Irina Kryuchkova $^{1}$ \\ ${ }^{1}$ Voronezh State Technical University, Moscow Avenue, 14, Voronezh, 394026, Russia
}

\begin{abstract}
In the Strategy for socio-economic development of the Voronezh region for the period until 2035, one of the main problems in the field of waste management is the rather low level of waste involvement in economic turnover. Improving of the current situation is expected by introducing resource-saving and low-waste technologies; implementation of a territorial and regional waste management program, as well as through the creation of an environmentally friendly waste management infrastructure. The implementation of these measures is expected within the framework of the state program "Protection of the Environment and Natural Resources" in order to increase the level of development of human capital and the quality of life of the population of the Voronezh region. In a scientific study a comparative analysis method was used. This article discusses the essence of the concept of the infrastructure of a waste processing cluster, infrastructure facilities are classified. The urgency of creating and the need to develop the infrastructure of a waste processing cluster on the territory of the Voronezh region is formulated. The main problems of the transition to a new waste management system are identified.
\end{abstract}

\section{Introduction}

For several decades, one of the most pressing problems in the field of environmental protection has been a rather low level of development of organizational waste recycling, which leads not only to a deterioration of the environmental situation, but also to a decrease in the quality of life of the population [1]. In the strategy for socio-economic development of the Voronezh region for the period until 2035, approved by the Law of the Voronezh Region dated December 20, 2018 No. 168-OZ, one of the priority directions for the development of the region in the field of environmental management and environmental safety was named the project for the construction of eight inter-municipal ecological waste processing clusters (IMEWPC): Voronezhskiy IMEWPC, Paninskiy IMEWPC, Buturlinovskiy IMEWPC, Kalacheevskiy IMEWPC, Rossoshanskiy IMEWPC, Bogucharskiy IMEWPC, Liskinskiy IMEWPC, Borisoglebskiy IMEWPC Through the construction of waste sorting complexes and modern landfills for waste disposal under this project, by the end of 2035 it is planned to obtain the following results:

- increase in the share of neutralized and used waste up to $80 \%$;

*Corresponding author: sea-parish@mail.ru 
- increase in the share of utilized waste up to $30 \%$;

- increase in coverage of the territory of the Voronezh region for the collection, recycling and processing of waste up to $100 \%$;

- increasing the level of ecological culture of the population of the region;

- introduction and application of resource-saving and low-waste technologies;

- creation and development of infrastructure for the disposal and recycling of waste.

The creation and development of the infrastructure for safe waste management can be called the main direction in ensuring the environmental safety of the region, since its presence makes it possible to extract the resource potential of the waste and introduce restrictions on their disposal [2].

The works of P.A.Shokhova, L.G.Elkina and N.G.Kopeikina[3] are devoted to the research of the cluster approach in the field of environmental management and environmental protection. Issues of strategic planning of the waste processing industry are considered by E.S. Tskhovrebov [4]. The formation of an organized recycling system was investigated in the works of E.S. Zemskova [5]. Works of Ya.S. Bakhovaya and E.N. Zakharova devoted to the consideration of environmental innovation as a factor in sustainable regional development [6].

Despite the fact that the issues of the formation of ecological clusters are rather widely considered in the scientific literature, the features of the formation of an infrastructure for the safe management of waste remain insufficiently studied. This determines the relevance of the selected topic. What is the infrastructure of the waste processing cluster, what is its essence and what tasks does its formation solve is the goal of this study [7-14].

\section{Materials and methods}

The object of scientific research is the infrastructure of the waste processing cluster. The main method for conducting this research is the analysis of regulatory legal acts, standards in the field of waste management, as well as research materials on this topic.

For the first time, the concept of infrastructure in the economy was used by $\mathrm{P}$. Rosenstein-Rodea in the middle of the 20th century as "a set of general conditions ensuring the favorable development of private entrepreneurship in the main sectors of the economy and satisfying the needs of the entire population" [7]. The main elements of infrastructure, he called a set of production and social conditions that ensure the economic efficiency of production and development of society.

I. Mayergoyz, E. Alaev and S. Debabov [7] were the first in the domestic economy to consider the term in the field of the effective allocation of production forces. In the modern sense, infrastructure is "a set of enterprises, institutions, management systems, communications, etc., supporting the activities of society or any of its spheres" [8].

The scientific works of T.N. Somova and Oshchepkova A.Z. are devoted to the study of the essence of infrastructure in the field of safe waste management. As a result of the study of this issue, they came to the conclusion that the waste management infrastructure is the main subsystem of the ecological infrastructure, the elements of which are aimed at ensuring conditions for preserving the "human environment" [9]. The totality of Oschepkova A.Z. Waste management infrastructure facilities is presented in table 1.

Table 1. Waste Management Infrastructure Facilities.

\begin{tabular}{|c|l|}
\hline $\begin{array}{c}\text { Classification of waste management } \\
\text { infrastructure facilities }\end{array}$ & Infrastructure facilities \\
\hline \multirow{2}{*}{$\begin{array}{c}\text { The major infrastructure facilities } \\
\text { (directly handling waste) }\end{array}$} & Facilities that collect, neutralize, dispose waste. \\
\cline { 2 - 2 } & Facilities that recycle waste. \\
\cline { 2 - 2 } & Facilities that transport waste. \\
\hline
\end{tabular}


Supporting infrastructure facilities (support the functioning of the major infrastructure facilities)

Facilities that design and realize the technologies
and equipment in the field of waste neutralization
and disposal.
Facilities that manufacture equipment in the field
of waste management.
Facilities that implement innovations in the field
of waste management.
Facilities that train specialists in the field of
waste management.
Facilities that regulate and control the activities
in the field of waste management.
Facilities that provide information in the field of
waste management.
Facilities that financially serve the activities in
the field of waste management.
Patent services and certification bodies.

Each waste processing cluster has its own infrastructure in the field of waste management, depending on the sources and volumes of waste generation, especially the territorial distribution and specialization of infrastructure facilities.

Analysis of the stages of the waste life cycle is the main method for creating an effective waste management system that allows to determine the most appropriate way to process waste.

In the national standard of the Russian Federation GOST R 53692 - 2009, on a recommendation basis, the main stages of the technological cycle of waste generated in industry, construction, agriculture and households are identified. The characteristics of the stages of the waste life cycle are presented in table 2.

Table 2. Description of the main stages of the waste life cycle.

\begin{tabular}{|c|l|l|}
\hline № & \multicolumn{1}{|c|}{$\begin{array}{c}\text { The name of the stage of the } \\
\text { waste life cycle }\end{array}$} & \multicolumn{1}{c|}{ Waste Life Cycle Characterization } \\
\hline 1 & Appearance & $\begin{array}{l}\text { The stage begins immediately after consumption of the } \\
\text { product or as a result of technological or operational } \\
\text { processes. }\end{array}$ \\
\hline 2 & Collection and accumulation & $\begin{array}{l}\text { Reception of waste is carried out in mixed or separate } \\
\text { form on an authorized territory from individuals or } \\
\text { legal entities. }\end{array}$ \\
\hline 3 & Identification & $\begin{array}{l}\text { At this stage, in accordance with the approved } \\
\text { requirements, the waste is classified. }\end{array}$ \\
\hline 4 & Sorting & $\begin{array}{l}\text { Mixed waste, in accordance with certain criteria, is } \\
\text { divided into components and, if necessary, undergo } \\
\text { primary disposal, i.e. changing physical or chemical } \\
\text { properties in order to minimize the environmental } \\
\text { impact of waste. }\end{array}$ \\
\hline 5 & Certification & $\begin{array}{l}\text { The established forms of the passport of waste are filled } \\
\text { and registered in accordance with the adopted } \\
\text { legislation on environmental protection. }\end{array}$ \\
\hline 6 & Packaging and labeling & $\begin{array}{l}\text { The integrity and safety of waste is ensured through } \\
\text { packaging with appropriate marking. }\end{array}$ \\
\hline 7 & Transportation and placement & $\begin{array}{l}\text { Sorted and packaged waste is transported by means of } \\
\text { vehicles to authorized landfills, waste sorting, waste } \\
\text { recycling or incinerator complexes. Warehousing is } \\
\text { carried out in specially designated places for long-term } \\
\text { storage. }\end{array}$ \\
\hline 8 & Storage & \begin{tabular}{l} 
Depending on the hazard class of the waste, storage can \\
\hline
\end{tabular}
\end{tabular}




\begin{tabular}{|l|l|l|}
\hline & $\begin{array}{l}\text { be carried out under a canopy, in containers or other } \\
\text { specially equipped places for further disposal. During } \\
\text { disposal, the waste is isolated in order to prevent the } \\
\text { release of any harmful substances into the environment. }\end{array}$ \\
\hline 9 & Disposal & $\begin{array}{l}\text { The waste life cycle ends with the extraction of useful } \\
\text { products or resources from the waste. Residues from } \\
\text { waste processing are disposed of in landfills. }\end{array}$ \\
\hline
\end{tabular}

Thus, the main infrastructure objects of safe waste management include facilities that are involved in various stages of the waste life cycle. These include waste collection sites and secondary raw materials, waste sorting and waste processing complexes, landfills.

\section{Results}

The territorial waste management system of the Voronezh region involves the creation of a waste processing cluster, which will include that part of the waste management infrastructure that is aimed at the use of waste resources. The main goal of such a cluster is to ensure the effective interaction of specialists from various industries involved in waste processing.

The concept of a waste processing cluster, in our opinion, quite accurately reveals the definition of a "cluster of waste processing facilities" proposed by A. Plotnikov and Zakharchenko E.S. : "a cluster of waste processing facilities is a territorial system that ensures the coordinated interaction of the subjects of treatment of production and consumption waste for the implementation of flows of secondary material resources in order to ensure an environmentally friendly living environment" [10]. Plotnikov A.P. and Zakharchenko E.S. consider this type of cluster as innovative, because it includes subjects from various industries. Waste is generated in one industry, and the secondary resources derived from them can be used in many other industries. This contributes to the consolidation of knowledge, obtaining innovative solutions and the introduction of economically and environmentally efficient technologies in the field of waste management. The implementation of the concept of sustainable development of the region is possible if environmental problems are addressed through the implementation of innovative achievements [11].

Thus, the infrastructure of the waste processing cluster can be defined as a complex of facilities and organizations that implement environmental, economic, technological and social tasks in the field of education and disposal of waste. The main goal of forming the infrastructure of the waste processing cluster is to create conditions for the effective interaction of cluster members.

\section{Discussions}

The assessment of the actual state of the inter-municipal ecological waste processing cluster of the Voronezh region has not yet been carried out. This can be explained by the fact that the formation of the inter-municipal cluster is not yet completed. Currently, only the Voronezh waste processing cluster and the Povorinsky waste sorting complex are operational. The design and construction of the remaining waste sorting complexes and landfills for waste disposal is expected to be completed by 2024. The amount of funding for the formation of the IMEWPC of the Voronezh region was approved by the regional program of the Voronezh region in the field of waste management (approved by the Government of the Voronezh region dated June 30, 2017 No. 524 "On Amending the Government of the Voronezh region dated 11.11.2015 No. 856") and presented table 3. 
Table 3. The amount of funding for formation of the infrastructure of the waste processing cluster.

\begin{tabular}{|c|c|c|}
\hline № & $\begin{array}{c}\text { The name of the inter-municipal } \\
\text { ecological waste processing cluster } \\
\text { (IMEWPC) }\end{array}$ & $\begin{array}{c}\text { The amount of funding for the creation of } \\
\text { waste sorting complexes and landfills, } \\
\text { (millions of rubles) }\end{array}$ \\
\hline 1 & PaninskiyIMEWPC & 298 \\
\hline 2 & Buturlinovskiy IMEWPC & 326 \\
\hline 3 & Kalacheevskiy IMEWPC & 203 \\
\hline 4 & Rossoshanskiy IMEWPC & 403 \\
\hline 5 & Bogucharskiy IMEWPC & 268 \\
\hline 6 & Liskinskiy IMEWPC & 733 \\
\hline 7 & Borisoglebskiy IMEWPC & 663 \\
\hline & TOTAL & 2894 \\
\hline
\end{tabular}

The total amount of funding required for the implementation of environmental protection measures envisaged by the Strategies for the socio-economic development of the Voronezh region for the period until 2035 is almost 32 billion rubles. The bulk of these funds are funds from non-budget sources. This is due to the economic downturn, the volume of public investment in the economy is also declining. This problem has recently been solved through the principle of public-private partnership, which allows combining financial and administrative resources of the state and private investors, in particular for investment in the waste processing industry [12].

In the process of transition to a new waste management system, the following main problems were identified, which are presented in table 4 [1]. Correcting them in a timely manner will make it possible to increase the effectiveness of the measures being taken to form the infrastructure of the inter-municipal ecological waste processing cluster.

Analyzing the problem of the transition to the new waste management system, identified by M.V.Latypova, we can conclude that the main problem that needs special attention is the lack of an effective system for separate waste collection. The limiting factors for the implementation of separate waste collection are the lack of environmental education and public education, the lack of administrative and economic incentives for waste sorting, and the need for special equipment for waste collection sites. Proper organization of waste sorting will significantly reduce the cost of waste processing and improve the quality of this process.

Table 4. The main problems of the transition to a new waste management system.

\begin{tabular}{|l|l|}
\hline $\begin{array}{l}\text { The name of the stage } \\
\text { of waste management }\end{array}$ & \multicolumn{1}{|c|}{ The core of the problem } \\
\hline Waste collection & $\begin{array}{l}\text { There is no incentive system to reduce waste generation. There is no } \\
\text { effective system for separate waste collection. }\end{array}$ \\
\hline Storage & $\begin{array}{l}\text { Waste accumulation rates are underestimated in order to reduce payments } \\
\text { for regional operator services. }\end{array}$ \\
\hline Transportation & $\begin{array}{l}\text { Monopolization of the market for waste transportation by regional } \\
\text { operators }\end{array}$ \\
\hline Processing & $\begin{array}{l}\text { Tariff increase due to the lack of an effective separate waste collection } \\
\text { system. }\end{array}$ \\
\hline Utilization & $\begin{array}{l}\text { The lack of an effective system for separate collection of waste leads to a } \\
\text { decrease in the quality of waste processing and the profitability of waste } \\
\text { processing facilities. }\end{array}$ \\
\hline Placement & Most landfill sites do not comply with environmental safety standards \\
\hline
\end{tabular}

\section{Conclusion}


The formation of an effective infrastructure of the inter-municipal ecological waste processing cluster of the Voronezh region is a long and complex process, requiring consolidated efforts both from the legislative and executive authorities, as well as from private economic entities and the population.

The complex of infrastructure facilities in the field of waste processing is more dependent on the sources and volumes of waste generation, and the features of their territorial location. It is advisable to determine the method of processing the resulting waste on the basis of the stages of their life cycle.

For the timely implementation of the regional policy on creating the infrastructure of inter-municipal waste processing clusters, it is necessary to create favorable conditions for public-private partnerships in order to attract additional investment.

The lack of an effective separate waste collection system is a major problem in the transition to a new waste management system.

The creation and development of infrastructure in the field of waste processing will ensure the sustainable development of our region in the field of environmental management and environmental safety

\section{References}

1. M.V. Latypova, National interests: priorities and safety 14(4), 741 - 758 (2018) https://doi.org/10.24891/ni.14.4.741

2. E.N. Zhutaeva, E.A. Serebryakova, I.V. Kryuchkova, Economics and Entrepreneurship 9-4(86), 979-98 (2017)

3. P.A. Shokhov, L.G. Elkina, N.G. Kopeikina, Bulletin of USATU. Economics and national economy management 16.18(53), 170-175 (2012)

4. E.S. Tskhovrebov, Vestnik MGSU 13.10, 1193-1203 (2018) DOI: 10.22227/19970935.2018.10.1193-1203

5. E.S. Zemskova Scientific journal NRU ITMO, Series: Economics and Environmental Management 4, 125-134 (2017) DOI: 10.17586 / 2310-1172-2017-10-4-125-134

6. Ya.S. Bakhova, E.N. Zakharova, Innovative Economy: Prospects for Development and Improvement 1(27) (2018)

7. E.F. Nikitskaya, A.E. Poikin, Internet journal "SCIENCE" 8.2 (2016) DOI: 10.15862 / 77EVN216

8. The large explanatory dictionary of the Russian language (Norint, St. Petersburg, 2000) ISBN 5-7711-0015-3

9. T.N. Somova, A.Z. Oshchepkova, V.A. Stolbov, Bulletin of PNIPU, Urban Studies 3, 7-23 (2012)

10. A.P. Plotnikov, E.S. Zakharchenko, Principles of forming an innovative cluster of waste disposal facilities, innclub.info

11. K. Kulakov, S. Belyaeva, O. Belyantseva, A. Gamisoniya, MATEC Web of Conferences 170, 01118 (2018)

12. V.V. Gasilov, I.V. Kryuchkova, Scientific Herald of the Voronezh State University of Architecture and Civil Engineering, Series: High Tech. Ecology 1, 44-46 (2016)

13. V.N. Chechevichkin, N.I. Vatin. Magazine of Civil Engineering. 2014. 50(6). Pp. 6774. DOI:10.5862/MCE.50.7.

14. J. Dražić, N. Vatin. Procedia Engineering. 2016. 165. Pp. 883-890.

DOI:10.1016/j.proeng.2016.11.788. 